Original research article

\title{
Quality of life of Czech patients with diabetic foot ulcers
}

\author{
Radka Vymětalová ${ }^{1}$, Renáta Zeleníková ${ }^{2}$ * \\ ${ }^{1}$ Hospital Přerov, Home care Department, Přerov, Czech Republic \\ ${ }^{2}$ University of Ostrava, Faculty of Medicine, Department of Nursing and Midwifery, Ostrava, Czech Republic
}

\begin{abstract}
Aim: The aim of this study was to assess the quality of life of patients with diabetic foot ulcers, and its dependence on the duration of ulceration, the use of insulin therapy, smoking and Body Mass Index.

Design: Cross-sectional study.

Methods: A standardized questionnaire, the Diabetic Foot Ulcer Scale, was used for data collection. A quantitative study included 247 adults with diabetic foot ulcers. Data collection was performed between April 2014 and December 2014 in 18 podiatric outpatient and chronic wound outpatient clinics spread out over the entire Czech Republic.

Results: The study found that the highest average index of quality of life was in the domain of noncompliance (84.6), while the lowest was in the domain of leisure (49.2). The duration of diabetic foot ulcer has significant influence on three domains of quality of life: physical health $(p=0.022)$, noncompliance $(p=0.044)$ and positive attitude $(p=0.018)$. The use of insulin therapy has an important influence on three domains of quality of life: physical health $(p=0.002)$, daily activities $(p=0.012)$ and emotions $(p=0.029)$. Statistically significant differences in quality of life scores have been found between smokers and non-smokers in two domains: noncompliance $(p<0.0001)$ and positive attitude $(p=0.003)$.

Conclusions: In our sample it was demonstrated that quality of life is dependent on the duration of diabetic foot ulcers - the longer the duration, the lower the quality of life. The dependence was revealed in three domains: physical health, noncompliance and positive attitude. The use of insulin therapy as well as smoking proved to have an impact on the quality of life of patients with diabetic foot ulcers. The use of insulin therapy as well as smoking proved to have an impact on the quality of life of patients with diabetic foot ulcers. Prevention, early detection and monitoring of diabetic foot ulcers is necessary in order to prevent continuing deterioration of quality of life of diabetic patients.
\end{abstract}

Keywords: Diabetic foot ulcers; Diabetic Foot Ulcers Scale; Diabetes mellitus; Health-related quality of life

\section{Introduction}

Diabetes mellitus is one of the major diseases affecting humankind. Diabetic ulceration within the diabetic foot is one of the most serious and significant complications of diabetes, and it is estimated, that it affects about $15 \%$ of diabetics over the course of their lives (Rasouli et al., 2011). In elderly patients the incidence of diabetic ulceration is higher, in comparison to the general population (Brem et al., 2003). Diabetic ulcers negatively affect the physical function, psychological status and social situation of patients (Goodridge et al., 2005; Meijer et al., 2001; Özlem et al., 2014; Willrich et al., 2005). All these negative effects compromise the quality of life of these patients. Patients with ulcerations have a very poor health-related quality of life (HRQoL) compared to diabetic patients without ulceration (Sekhar et al., 2015). For example, it has been demonstrated that a third of people with diabetic foot ulcers suffer from clinical depression. Depressive symptoms are associated with more compromised overall diabetic self-care and health-related quality of life (Pearson et al., 2014).
That diabetic ulcers are a significant problem is underscored by the fact that people with this complication are at greater risk of death (Ismail et al., 2007; Sehlo et al., 2016). Qualitative studies confirm the clinical observation that diabetic foot ulcers have a huge negative psychological and social impact, including reduced social activity, increased tension in the family, restrictions on employment and financial hardship (Goodridge et al., 2005). Data from the Institute of Health Information and Statistics of the Czech Republic (covering the year ending Dec. 31, 2013) show a continuing trend of increased incidence of diabetes mellitus, which affected over $8.2 \%$ of the population (ÚZIS ČR, 2015). According to the Institute of Health Information and Statistics of the Czech Republic, there were 927,830 diabetics in 2015. In 2013, there were 44,657 diabetic patients with diabetic foot in the Czech Republic (ÚZIS ČR, 2015).

Podiatric care in the Czech Republic is organized on three levels: the minimal model (a doctor trained in podiatry and a podiatric nurse working in a hospital or outpatient setting), the intermediate model (foot clinic) and a third model represented by a specialized podiatric workplace. According to data of

\footnotetext{
* Author for correspondence: Renáta Zeleníková, University of Ostrava, Faculty of Medicine, Department of Nursing and Midwifery, Syllabova 19, 70300 Ostrava, Czech Republic; e-mail: renata.zelenikova@osu.cz

http://doi.org/10.32725/kont.2019.014

Submitted: 2018-08-19 • Accepted: 2019-01-23 • Prepublished online: 2019-03-05

KONTAKT 21/1: 8-13 • EISSN 1804-7122 • ISSN 1212-4117

(c) 2019 The Authors. Published by University of South Bohemia in České Budějovice, Faculty of Health and Social Sciences.

This is an open access article under the CC BY-NC-ND license.
} 
the Czech Diabetes Society (Česká diabetologická společnost, 2018), there are 32 foot clinics in the Czech Republic. Podiatry clinics provide multi-disciplinary care, and their staff typically includes a diabetologist, general surgeon, vascular surgeon, interventional radiologist, orthopedist, podiatric nurse, a prosthetics/orthoptist, a rehabilitation team, a psychologist, a microbiologist and a shoe manufacturer (Jirkovská, 2006).

Diabetic foot ulcer is one of the major complications of diabetes that affects quality of life. To assess the impact of diabetic ulcers on the quality of life of patients with diabetic foot disease, a specific questionnaire was designed; the Diabetic Foot Ulcer Scale (DFSC) (Abetz et al., 2002). The questionnaire, DFS (DFS@ 1999 Janssen Global Services, LLC USA. All rights reserved), is considered a disease-specific instrument that measures the specific factors affecting the lives of patients with diabetic foot ulcers. Studies have demonstrated sensitivity in patients with healed and unhealed ulcers as well as changes in the state of the wound. This questionnaire was originally developed by Johnson \& Johnson (ICOM Economic Health, USA) and has been translated into more than 40 languages (Valensi et al., 2005).

\section{Aim}

The aim of this study was to assess the quality of life of patients with diabetic foot ulcers, and its dependence on the duration of ulceration, the use of insulin therapy, smoking and Body Mass Index.

\section{Materials and methods}

\section{Design}

Cross-sectional study.

\section{Instrument}

The Czech version of the standardized questionnaire - the Diabetic Foot Ulcer Scale (DFS) - was used for data collection. The DFS standardized questionnaire consists of 58 items, which are classified into 11 domains: leisure; natural health; daily activities; emotions; noncompliance; family; friends; treatment; satisfaction; positive attitude and finance. Each domain has 1 to 17 questions which respondents answer by circling digits on the Likert scale of 1-5 (with some questions scored on a scale of $0-5$ ). The index of health-related quality of life is a number from 0 to 100 , which indicates the quality of life of the patient in a certain area (domain) of his or her life that is affected by the disease. Higher scores indicate better quality of life (Janssen Global Services et al., 2002).

The following demographic and clinical data were collected: age, gender, marital status, education, duration of ulceration, type of diabetes, treatment of diabetes, smoking, height and weight. Approval of the translation and permission to use the DFS questionnaire were sought from the MAPI Research Institute. The linguistic validation process was carried out according to the standard recognized methodology of translation, as described in Acquadro, Conway, Giroudet, Mear: Linguistic Validation Manual of Patient-Reported Outcomes, MAPI Institute 2005. The methodology included forward translation, backward translation, review by clinicians, cognitive interviews and a report. The linguistic validation process took 10 weeks (Mapi Research Institute, 2002).

\section{Sample}

The group consisted of patients with type 1 and 2 diabetes mellitus, with at least one diabetic foot ulcer, who visited a chronic wounds outpatient clinic or a foot clinic. Non-probability purposive sampling was used. The patients were involved in the study by clinicians from chronic wounds outpatient clinics or foot clinics who had accepted invitations to participate in this study. Patients were recruited consecutively as they visited a clinic. The sample consisted of 247 patients with diabetic foot ulcer in the age range of 24-90 years.

\section{Data collection}

Of the 33 foot clinics which were interviewed by email, 21 clinics agreed to participate in the research. A total of 18 foot clinics were involved in the final phase of the research, submitting completed questionnaires. Staff of these foot clinics, as well as a main researcher, administered the questionnaires directly to the patients in paper-and-pencil form. Printed questionnaires were distributed to foot clinics by mail or personally by the main researcher. Data were collected from April 2014 through December 2014.

\section{Statistical methods}

Because the Shapiro-Wilk test for normality showed that the variables investigated do not have a normal distribution, the Kruskal-Wallis test and the Mann-Whitney U-test were used for statistical analysis. All statistical tests were performed at the level of significance 0.05. Statistical software Statistics for Windows SPSS, Version 22.0 (Armonk, New York: IBM Corp.) was used for the statistical evaluation.

\section{Results}

\section{Participants}

Demographic and clinical data are presented in Table 1.

The lowest quality of life score was found in the domain of leisure (49.2), where quality of life was affected by decreased enjoyment of holidays, hobbies and leisure activities. At the other end, the highest quality of life score was found in the domain of noncompliance (84.6), which concerns how respondents implement the directives or recommendations of their physicians (Table 2).

\section{Quality of life in relation to the duration of ulceration}

The Kruskal-Wallis test showed a statistically significant relationship between quality of life and duration of diabetic foot ulcers in the domains of physical health, noncompliance and positive attitude (Table 3). Patients with a longer duration of ulceration had a lower quality of life index in these domains. In other domains statistically significant differences in relation to duration of diabetic foot ulcer were not detected. It was demonstrated that quality of life is dependent on the duration of diabetic foot ulcers - the longer the duration, the lower the quality of life. This study established this dependence in three domains: physical health, noncompliance and positive attitude.

\section{Quality of life in relation to usage of insulin}

The Mann-Whitney U-test demonstrated a statistically significant difference between the quality of life of patients who received insulin and those who did not use it in the domains of physical health, daily activities and emotions. Patients who were not using insulin had significantly higher quality of life scores in these domains (Table 4). 


\section{Table 1. Demographic and clinical data $(n=247)$}

\begin{tabular}{|c|c|c|}
\hline Characteristics & Absolute frequency & Relative frequency \\
\hline \multicolumn{3}{|l|}{ age } \\
\hline under 65 years & 123 & $49.8 \%$ \\
\hline over 65 years & 124 & $50.2 \%$ \\
\hline \multicolumn{3}{|l|}{ gender } \\
\hline male & 177 & $71.7 \%$ \\
\hline female & 70 & $28.3 \%$ \\
\hline \multicolumn{3}{|l|}{ duration of ulceration } \\
\hline up to 2 months & 13 & $5.3 \%$ \\
\hline $2-5$ months & 25 & $10.1 \%$ \\
\hline 5-12 months & 30 & $12.1 \%$ \\
\hline more than 1 year & 179 & $72.5 \%$ \\
\hline \multicolumn{3}{|l|}{ type of diabetes } \\
\hline type 1 & 42 & $17.0 \%$ \\
\hline type 2 & 205 & $83.0 \%$ \\
\hline \multicolumn{3}{|l|}{$\begin{array}{l}\text { peroral antidiabetic } \\
\text { therapy }\end{array}$} \\
\hline yes & 82 & $33.2 \%$ \\
\hline no & 165 & $66.8 \%$ \\
\hline \multicolumn{3}{|l|}{ insulin therapy } \\
\hline yes & 168 & $68.0 \%$ \\
\hline no & 79 & $32.0 \%$ \\
\hline \multicolumn{3}{|l|}{ smoking } \\
\hline yes & 38 & $15.4 \%$ \\
\hline no & 209 & $84.6 \%$ \\
\hline \multicolumn{3}{|l|}{ BMI } \\
\hline underweight & 1 & $0.4 \%$ \\
\hline optimal weight & 38 & $15.4 \%$ \\
\hline overweight & 83 & $33.6 \%$ \\
\hline obesity 1st stage & 85 & $34.4 \%$ \\
\hline obesity 2nd stage & 31 & $12.6 \%$ \\
\hline obesity 3rd stage & 9 & $3.6 \%$ \\
\hline
\end{tabular}

Table 2. Average values of health-related quality of life score ( $n=247)$

\begin{tabular}{lccccc} 
Domains & Average & SD & Median & Minimum & Maximum \\
\hline leisure & 49.2 & 31.4 & 45.0 & 0.0 & 100.0 \\
physical health & 61.8 & 22.6 & 62.5 & 4.2 & 100.0 \\
daily activities & 59.4 & 27.6 & 62.5 & 0.0 & 100.0 \\
emotions & 55.9 & 24.3 & 55.9 & 4.4 & 100.0 \\
noncompliance & 84.6 & 18.2 & 87.5 & 0.0 & 100.0 \\
family & 78.1 & 20.4 & 85.0 & 0.0 & 100.0 \\
friends & 74.8 & 21.3 & 80.0 & 0.0 & 100.0 \\
treatment & 62.8 & 22.9 & 65.6 & 0.0 & 100.0 \\
satisfaction & 80.6 & 20.5 & 75.0 & 25.0 & 100.0 \\
positive & & & & & \\
attitude & 53.2 & 23.4 & 55.0 & 0.0 & 100.0 \\
financial & 58.5 & 23.0 & 62.5 & 0.0 & 100.0 \\
\hline
\end{tabular}

Average - average scores; SD - standard deviation.

\section{Quality of life in relation to smoking}

The Mann-Whitney $U$-test demonstrated a statistically significant difference between the quality of life of patients who smoked and those who did not smoke in the domains of noncompliance and positive attitude. As seen in Table 5, patients who smoked had a lower quality of life index in these domains.
Table 3. Average quality of life score in relation to the duration of ulceration

\begin{tabular}{lccccc} 
Domains & $\begin{array}{c}\text { Up to 2 } \\
\text { months }\end{array}$ & $\begin{array}{c}\text { 2-5 } \\
\text { months }\end{array}$ & $\begin{array}{c}5-12 \\
\text { months }\end{array}$ & $\begin{array}{c}\text { More than } \\
\text { 1 year }\end{array}$ & $\begin{array}{c}P \\
\text { value }\end{array}$ \\
\hline leisure & 64.23 & 54.38 & 41.67 & 48.73 & 0.159 \\
physical health & 78.21 & 65.97 & 61.17 & 60.10 & 0.022 \\
daily activities & 59.62 & 60.67 & 62.08 & 58.73 & 0.927 \\
emotions & 66.73 & 57.22 & 56.49 & 54.78 & 0.429 \\
noncompliance & 93.27 & 89.00 & 88.75 & 82.68 & 0.044 \\
family & 84.81 & 81.20 & 80.39 & 76.85 & 0.450 \\
friends & 81.54 & 78.60 & 76.17 & 73.58 & 0.039 \\
treatment & 70.67 & 62.75 & 63.75 & 62.01 & 0.468 \\
satisfaction & 86.54 & 80.00 & 70.83 & 81.96 & 0.078 \\
positive & & & & & \\
attitude & 66.83 & 49.69 & 61.16 & 51.33 & 0.018 \\
finance & 59.62 & 58.85 & 58.75 & 58.29 & 1.000 \\
\hline
\end{tabular}

$P$ - level of significance.

Table 4. Average quality of life score in relation to insulin usage

\begin{tabular}{lccc} 
Domains & Smokers & Non-smokers & $P$ value \\
\hline leisure & 47.08 & 53.85 & 0.123 \\
physical health & 58.47 & 68.70 & 0.002 \\
daily activities & 56.25 & 66.03 & 0.012 \\
emotions & 53.51 & 60.88 & 0.029 \\
noncompliance & 85.34 & 83.07 & 0.264 \\
family & 78.73 & 76.88 & 0.662 \\
friends & 74.24 & 76.08 & 0.591 \\
treatment & 62.31 & 63.69 & 0.711 \\
satisfaction & 81.63 & 78.53 & 0.309 \\
positive attitude & 54.00 & 51.47 & 0.449 \\
finance & 58.31 & 58.81 & 0.929 \\
\hline P-level of significance. & & \\
\hline
\end{tabular}

Table 5. Average quality of life score in relation to smoking

\begin{tabular}{lccc} 
Domains & Smokers & Non-smokers & $P$ value \\
\hline leisure & 50.10 & 49.09 & 0.937 \\
physical health & 62.32 & 61.67 & 0.720 \\
daily activities & 59.32 & 59.39 & 0.926 \\
emotions & 55.97 & 55.85 & 0.968 \\
noncompliance & 72.37 & 86.84 & $<0.0001$ \\
family & 75.81 & 78.55 & 0.398 \\
friends & 69.87 & 75.73 & 0.230 \\
treatment & 61.84 & 62.92 & 0.788 \\
satisfaction & 76.32 & 81.43 & 0.231 \\
positive attitude & 43.82 & 54.88 & 0.003 \\
finance & 57.09 & 58.71 & 0.698 \\
\hline
\end{tabular}

$P$ - level of significance. 


\section{Quality of life in relation to BMI}

The Kruskal-Wallis test did not demonstrate any statistically significant dependence of the quality of life of patients on BMI (Table 6).

\section{Table 6. Average quality of life score in relation to Body Mass Index}

\begin{tabular}{|c|c|c|c|c|c|c|}
\hline Domains & Optimal weight & Overweight & Obesity 1st stage & Obesity 2nd stage & Obesity 3rd stage & $P$ value \\
\hline leisure & 54.18 & 50.25 & 48.80 & 43.96 & 45.56 & 0.749 \\
\hline physical health & 63.29 & 61.40 & 63.96 & 56.29 & 59.26 & 0.522 \\
\hline daily activities & 61.10 & 55.12 & 61.67 & 65.32 & 54.17 & 0.318 \\
\hline emotions & 58.09 & 55.18 & 56.48 & 56.07 & 50.67 & 0.908 \\
\hline noncompliance & 89.14 & 89.14 & 83.24 & 81.85 & 86.11 & 0.358 \\
\hline family & 76.51 & 77.45 & 80.40 & 73.06 & 87.34 & 0.329 \\
\hline friends & 74.87 & 75.27 & 77.18 & 70.17 & 66.67 & 0.512 \\
\hline treatment & 66.61 & 63.40 & 61.10 & 62.92 & 58.33 & 0.789 \\
\hline satisfaction & 82.89 & 80.18 & 78.57 & 82.50 & 88.89 & 0.501 \\
\hline positive attitude & 51.42 & 53.58 & 53.19 & 55.48 & 48.44 & 0.925 \\
\hline finance & 63.16 & 61.45 & 57.68 & 51.61 & 45.83 & 0.130 \\
\hline
\end{tabular}

\section{Discussion}

The aim of this research was to evaluate the health-related quality of life of diabetic patients with foot ulcers within the diabetic foot syndrome.

The study results showed that quality of life was dependent on the duration of diabetic foot ulcers - the longer the duration, the lower the quality of life. This relationship has been shown in three domains in this study: physical health, noncompliance and positive attitude. A very similar conclusion was reached by a team of French researchers, where the SF-36 questionnaire with another distribution of domains confirmed that patients with longer duration of ulceration had a more compromised quality of life in the domains of physical health, side effects, care and financial burden (Valensi et al., 2005). On the other side, another study found that ulcer duration shorter than 1 week and ranging from 1 week to 3 months affected HRQoL more negatively than ulcer duration greater than 3 months (Kiadaliri et al., 2013).

It has also been demonstrated that long-term, especially recurrent ulcers, are significantly associated with depressive symptoms and a more compromised mental condition (Iversen et al., 2009). Wexler et al. (2006), who obtained quality of life scores by using the Health Utilities Index Mark II (HUI-3) questionnaire, found that when using multivariable regression there did not appear to be a statistically significant link between the use of insulin and quality of life. But when using one-dimensional analysis, this connection was found to be significant, which therefore confirms that insulin use, in conjunction with the associated complications, reduces quality of life. This creates a dilemma. Some protocols recommend postponing insulin use in order not to compromise quality of life, but these protocols do not take into consideration the fact that insulin is one of the measures used to alleviate the symptoms of diabetes, intensified insulin therapy, or the use of an insulin pump being recommended for promoting the healing process (Pit'hová et al., 2007).
In regard to the relation between general quality of life and smoking, it has been demonstrated that when a patient first begins to smoke, there is a reduction in quality of life, especially in overall and mental health. With continued smoking, this deterioration is reflected in virtually all areas of life, but significantly, it manifests mainly in subjective feelings of health, the emotional, mental and cognitive areas, and in fatigue and pain. It has also been demonstrated that a lower quality of life (in general terms, not specifically in relation to diabetes) and a higher rate of depression are found in smokers compared to non-smokers (Goldenberg et al., 2014).

Similar research was carried out in Iran, where it has been shown that smokers, especially former smokers, had a poorer quality of life than those who had never smoked. This fact is independent of sociodemographic factors (Toghianifar et al., 2012). Part of the DFS questionnaire is the domain of failure, where respondents are asked how they go about complying with the recommendations and advice of their physicians. It turns out that one of the first pieces of advice that doctors give to patients with diabetic foot ulcers is to quit smoking. It has been demonstrated that this is at least partly adhered to, because there are more smokers among the general population (38\%) and the population with diabetes (37\%) than there are among patients with diabetic ulcerations (29\%) (Ribu et al., 2007). Smokers who give up the habit should then logically have a reduced quality of life in the domain of noncompliance. This study demonstrated that the quality of life score of smokers is lower not only in the domain of noncompliance, but also in the domain of positive attitude. This confirms the finding of Nasiriziba et al. (2015), who argue that smokers have negative emotions that arise as a result of their consciousness of the inability to give up smoking, and thus have a negative outlook on the world. Smokers are also more angry and depressed (Nasiriziba et al., 2015).

In this study we did not demonstrate the influence of BMI on quality of life. At first glance this is a surprising result, but it can be explained by the fact that people with higher BMI have a lower quality of life due to this fact alone, due to limitations, 
for example, in the domains of daily activity or physical health. The limitations placed on them by diabetic ulcers are not perceived by them as being so severe as to significantly worsen their quality of life. Another possible explanation that can be offered is that patients were trying to maintain a healthy weight, but that difficulties with the psychological management of diabetic foot ulcers caused them to suffer a certain feeling of hopelessness, making weight control no longer as important to them as working toward a cure for ulceration (Rasouli et al., 2011). The opposite result was demonstrated by a US team that examined the quality of life of Afro-American patients with diabetic foot ulcers. They succeeded in determining (using SF-36) that patients with a BMI between 30 and 35 had a quality of life that was on average 11 points lower than those who had a BMI of less than 30 . In patients with a BMI greater than 35, this difference rose to 17 points (HillBriggs et al., 2002).

Our result is inconsistent with the literature. However, patients with ulcers and higher-than-normal BMI can be indifferent to their health problems, and this could have repercussions on their subjective perception of their well-being. They could conceivably develop a fictitious sense of well-being (Kiadaliri et al., 2013).

Another important finding was the impact of the duration of ulceration and of the usage of insulin, because patients with longer-lasting ulcerations, especially those taking insulin, have significantly worse quality of life in three domains.

Abroad researchers have been able to demonstrate that patients with low quality of life are more likely to require ma- jor amputation or to face the risk of death. Unfortunately, the contrary result was not found, namely, that those with a high quality of life have improved chances of healing quickly (Siersma et al., 2014).

As in another paper (Vymětalová and Zeleníková, 2016), the results underline the importance of quality of life in the management of patients with diabetic foot syndrome.

\section{Conclusions}

The study results have shown that the quality of life of patients with diabetic ulcers is affected by the duration of ulceration, the use of insulin and smoking. In this study we did not demonstrate the influence of BMI on quality of life. These findings have implications for clinical decisions in patients with diabetic foot ulcers. Prevention, early detection and monitoring of diabetic foot ulcers is necessary in order to prevent continuing deterioration of quality of life in diabetic patients.

\section{Ethical aspects}

The research was approved by the Ethics Committee of the Faculty of Medicine, University of Ostrava (ID: 9/2014), and by the Ethics Committee of the General University Hospital, Prague (ID: 1664/14 S-IV), and was conducted in accordance with the Declaration of Helsinki.

\section{Conflict of interests}

The authors declare no conflict of interests.

\section{Kvalita života českých pacientů se syndromem diabetické nohy}

\section{Souhrn}

Cíl: Cílem této studie bylo zhodnotit kvalitu života pacientů se syndromem diabetické nohy a závislost kvality života na délce ulcerace, užívaní inzulinu, kouření a indexu tělesné hmotnosti.

Design: Průřezová studie.

Metodika: Pro sběr dat byl použit standardizovaný dotazník Diabetic Foot Ulcer Scale. Kvantitativní studie zahrnovala 247 pacientů se syndromem diabetické nohy. Sběr dat probíhal od dubna 2014 do prosince 2014 v 18 podiatrických ambulancích a ambulancích pro léčbu chronických ran na celém území České republiky.

Výsledky: Nejvyšší průměrný index kvality života byl zjištěn v doméně Nedodržování $(84,6)$, zatímco nejnižší v doméně Volný čas $(49,2)$. Délka trvání ulcerace měla signifikantní vliv na tři domény kvality života: Fyzické zdraví $(p=0,022)$; Nedodržování $(p=0,044)$ a Pozitivní postoj $(p=0,018)$. Užívání inzulinu mělo významný dopad na tři domény kvality života: Fyzické zdraví $(p=0,002)$; Denní aktivity $(p=0,012)$ a Emoce $(p=0,029)$. Statisticky významné rozdíly mezi kuřáky a nekuřáky ve skóre kvality života byly zjištěny ve dvou doménách: Nedodržování $(p<0,0001)$ a Pozitivní postoj $(p=0,003)$.

Závěr: V našem souboru bylo prokázáno, že kvalita života je závislá na délce trvání diabetické ulcerace - čím delší trvání, tím nižší kvalita života. Závislost přitom byla zjištěna ve třech doménách: Fyzické zdraví, Nedodržování a Pozitivní postoj. Kvalitu života pacientů s diabetickou ulcerací ovlivňuje také užívání inzulinu a kouření. Prevence, včasná detekce a sledování diabetických ulcerací jsou nezbytné, aby se zabránilo dalšímu zhoršování kvality života diabetických pacientů.

Klíčová slova: Diabetic Foot Ulcers Scale; diabetes mellitus; diabetická ulcerace; kvalita života související se zdravím

\section{References}

1. Abetz L, Sutton M, Brady L, McNulty, Gagnon DD (2002). The diabetic foot ulcer scale (DFS): a quality of life instrument for use in clinical trials. Practical Diabetes Int 19(6): 167-175. DOI: 10.1002/pdi.356.

2. Brem H, Tomic-Canic M, Tarnovskaya A, Ehrlich HP, BaskinBey E, Gill K (2003). Healing of elderly patients with diabetic foot ulcers, venous stasis ulcers, and pressure ulcers. Surg Technol Int 11: 161-167.
3. Česká diabetologická společnost (2018). Seznam podiatrických ambulancí a kontakty. [online] [cit. 2018-08-15]. Available from: http://www.diab.cz/seznam-podiatrickych-ambulanci

4. Goldenberg M, Danovitch I, IsHak WW (2014). Quality of life and smoking. Am J Addict 23(6): 540-562. DOI: 10.1111/j.1521-0391.2014.12148.x.

5. Goodridge D, Trepman E, Embil JM (2005). Health-related quality of life in diabetic patient with foot ulcers: literature review. J Wound Ostomy Continence Nurs 32(6): 368-377.

6. Hill-Briggs F, Gary TL, Hill MN, Bone LR, Brancati FL (2002). Health-related quality of life in urban African Americans 
with type 2 diabetes. J Gen Intern Med 17(6): 412-419. DOI: 10.1046/j.1525-1497.2002.11002.x.

7. Ismail K, Winkley K, Stahl D, Chalder T, Edmonds M (2007). A cohort study of people with diabetes and their first foot ulcer. Diabetes Care 30(6): 1473-1479. DOI: 10.2337/dc06-2313.

8. Iversen MM, Midthjell K, Tell GS, Moum T, Ostbye T, Nortvedt MW (2009). The association between history of diabetic foot ulcer, perceived health and psychological distress: the Nord-Trøndelag Health Study. BMC Endocr Disord 9: 18. DOI: 10.1186/1472-6823-9-18.

9. Janssen Global Services, LLC (USA), Mapi (2002). Scaling and Scoring of the Diabetic Foot Ulcer Scale (DFS). Version 2. DFS C 1999 Mapi Research Trust. [online] [cit. 2019-02-09]. Available from: https://eprovide.mapi-trust.org/instruments/diabeticfoot-ulcer-scale

10. Jirkovská A (2006). Podiatrické ambulance. In: Jirkovská A et al. (Eds). Syndrom diabetické nohy: komplexní týmová péče. Praha: Maxdorf.

11. Kiadaliri AA, Najafi B, Mirmalek-Sani M (2013). Quality of life in people with diabetes: a systematic review of studies in Iran. J Diabetes Metab Disord 12(1): 54. DOI: 10.1186/2251-658112-54.

12. Mapi Research Institute (2002). „Linguistic validation of patient reported outcomes measure“. (c) Mapi Research Institute.

13. Meijer JW, Trip J, Jaegers SM, Links TP, Smits AJ, Groothoff JW, Eisma WH (2001). Quality of life in patients with diabetic foot ulcers. Disabil Rehabil 23(8): 336-340.

14. Nasiriziba F, Rasouli D, Safaei Z, Rokhafrooz D, Rahmani A (2015). Factors associated with quality of life in patients with diabetic foot ulcers. JJCDC 4(1): e26598. DOI: 10.5812/ jjcdc.26598.

15. Özlem O, Nimet O, Sezer I, Serap Parlar K (2014). Healthrelated quality of life of patients with diabetes mellitus and diabetic foot in the southeastern Anatolia region of Turkey. IJCS 7(1): 176-187.

16. Pearson S, Nash T, Ireland V (2014). Depression symptoms in people with diabetes attending outpatient podiatry clinics for the treatment of foot ulcers. J Foot Ankle Res 7(1): 47. DOI: 10.1186/s13047-014-0047-4.

17. Pithová P, Pelikánová M, Kvapil M (2007). Defekty na končetinách u pacientů s diabetem mellitus. Medi pro Praxi 4: $161-164$

18. Rasouli D, Nasiriziba F, Nabiamjad R, Haghani H (2011). The quality of life in men and women with diabetic foot ulcer in selected hospitals of Tehran universities. J Jahrom Univ Med Sci 12(1): 38-45. DOI: 10.29252/jmj.9.1.38.
19. Ribu L, Hanestad BR, Moum T, Birkeland K, Rustoen T (2007). A comparison of the health-related quality of life in patients with diabetic foot ulcers, with a diabetes group and a nondiabetes group from the general population. Quali Life Res 16(2): 179-189. DOI: 10.1007/s11136-006-0031-y.

20. Sehlo MG, Alzahrani OH, Alzahrani HA (2016). Illness invalidation from spouse and family is associated with depression in diabetic patients with first superficial diabetic foot ulcers. Int J Psychiatry Med 51(1): 16-30. DOI: 10.1177/0091217415621032.

21. Sekhar MS, Thomas RR, Unnikrishnan MK, Vijayanarayana K, Rodrigues GS (2015). Impact of diabetic foot ulcer on healthrelated quality of life: A cross-sectional study. Semin Vasc Surg 28(3-4): 165-171. DOI: 10.1053/j.semvascsurg.2015.12.001.

22. Siersma V, Thorsen H, Holstein PE, Kars M, Apelqvist J, Jude EB (2014). Health-related quality of life predicts major amputation and death, but not healing people with diabetes presenting with foot ulcers: the Eurodiale study. Diabetes Care 37(3): 694-700. DOI: $10.2337 / \mathrm{dc} 13-1212$.

23. Toghianifar N, Najafian J, Pooya A, Rabiei K, Eshrati B, Anaraki J, Sarrafzadegan N (2012). Association of smoking status with quality of life in a cross-sectional population-based sample of Iranian adults: Isfahan Healthy Heart Program. AsiaPac J Public Health 24(5): 786-794. DOI: $10.1177 / 1010539511403800$

24. ÚZIS ČR (2015). Činnost oboru diabetologie, péče o diabetiky $\mathrm{v}$ roce 2013. [Activity in the field of diabetology, care for diabetics in 2013]. [online] [cit. 2018-08-12]. Available from: http://www.uzis.cz/rychle-informace/cinnost-oborudiabetologie-pece-diabetiky-roce-2013

25. Valensi P, Girod I, Baron F, Moreau-Defarges T, Guillon P (2005). Quality of life and clinical correlates in patients with diabetic foot ulcers. Diabetes Metab 31(3 Pt 1): 263-271. DOI: DM-062005-31-3-1262-3636-101019-200514508.

26. Vymětalová R, Zeleníková R (2016). Painful ulceration and quality of life of patients with the diabetic foot syndrome. Cent Eur J Nurs Midw 7(4): 512-517. DOI: 10.15452/ CEJNM.2016.07.0023.

27. Wexler DJ, Grant RW, Wittenberg E, Bosch JL, Cagliero E, Delahanty L (2006). Correlates of health-related quality of life in type 2 diabetes. Diabetologia 49(7): 1489-1497. DOI: 10.1007/ s00125-006-0249-9.

28. Willrich A, Pinzur M, McNeil M, Juknelis D, Lavery L (2005). Health related quality of life, cognitive function, and depression in diabetic patients with foot ulcer or amputation. A preliminary study. Foot Ankle Int 26(2): 128-134. DOI: $10.1177 / 107110070502600203$. 